\title{
A research on determination of quality characteristics of chicken burgers produced with transglutaminase supplementation
}

\author{
Harun URAN ${ }^{1 \star}$, İsmail YILMAZ ${ }^{2}$
}

\begin{abstract}
Transglutaminases are enzymes that catalyze the cross-linking between peptides or proteins. They play an important role in heat stability, gel-formation capability, water-holding capacity, emulsification and nutritional properties of proteins. They are preferred in the use of a variety of meat products due to the binding properties. In this study the effect of transglutaminase on the quality characteristics of chicken burgers were investigated. The enzyme was added at 5 different concentrations $(0.2 \%, 0.4 \%, 0.6 \%, 0.8 \%$ and $1 \%)$ and the other treatments applied in burger production were followed. After the product was formed, it was left in the cold for a while and then analyses were carried out. According to the results, the enzyme contribution did not cause changes in the nutritional items (ash, fat, protein) of the product groups. However, there was a significant decrease in the cooking loss and a significant increase in the texture values in the groups in which the enzyme amount was increased. Although the texture of the products have been increased, the transglutaminase treatment did not effect sensory parameters of burgers compared to the control samples. Scanning Electron Microscopy (SEM) images also supported to the texture values of samples with the increase of cross-linking in microstructure.
\end{abstract}

Keywords: transglutaminase; chicken burger; quality; textural properties; microstructure.

Practical Application: The transglutaminase enzyme is able to reduce cooking loss by improving the textural properties of chicken burgers.

\section{Introduction}

Application of food processing supplements has recently become essential in food production. It is possible to change the physical, chemical and organoleptic properties of various products at will with the addition of certain food processing aids. Various food additives are used both in red meat and chicken meat production. Enzymes constitute a group of food processing aids used for this purpose and transglutaminase plays a substantial role among these enzymes.

Transglutaminase (TGase) is mostly used to improve functional properties of proteins in foods. The enzyme changes molecular structure of primary amines in proteins by catalyzing the bonding of various primary amines with $\gamma$-carboxylamine group of degraded glutamine. When amine is lacking as a substrate, TGase uses water molecules as emergency catchers to catalyze deamination of degraded glutamine. E-lysine crosslinking may be intra- or extra-molecular and may cause physical changes in protein-rich foods that particularly contain lysine and glutamine (Saguer et al., 2007). TGase may as well affect the other bonds in proteins (for instance bonds between meat and soy protein and casein and gluten, respectively). Besides, TGase generates cross-links by catalyzing the interactions between sulfhydryl and disulfide bonds with the addition of polifenoloxidase and lipoxygenase (Lantto et al., 2006). TGases can be obtained from miscellaneous animal and plant tissues and certain microorganisms. TGases derived from microorganisms (Microbial transglutaminase,
MTGase) are generally preferred in food industry since their production process is easy and cost-effective and they are commercially available. Thousands of microorganisms collaborate in the production of enzymes. The majority of microorganisms produce TGase by "Hydrometer Method". TGases are formed as their metabolic residues. This enzyme has the peculiar capability of changing protein chains from $\mathrm{G}$ to $\mathrm{L}$ form (Motoki \& Seguro, 1998). Streptoverticillium in particular (S. mobaraense ve S. griseocameun) is the most effectively used strain as a source of MTGase (Farnsworth et al., 2006).

The most important findings obtained from the studies regarding TGase are marked increases in the textural features and gel strength of the products. TGase supplementation was reported to provide firmer and tighter gel net formation through intermolecular $\varepsilon$ ( $\gamma$-glutamyl)-lysyl cross bindings (Nio et al., 1986; Tseng et al., 2000; Soares et al., 2004; Yokoyama et al., 2004; Sun \& Arntfield, 2011; Bourneow et al., 2012).

Meat products contain high levels of protein and myofibrillar proteins have marked influence on the textural quality of the products. Actin and myosin that constitute the majority of myofibrillar proteins are important substrates for TGases and can also be polymerized by TGase addition and thus improve the textural properties of gel structured meat products (Tseng \& Cheng, 2002). 
Numerous studies are available with respect to the usage of TGase in meat products. The enzyme is administered at low temperature $\left(10^{\circ} \mathrm{C}\right)$ conditions as well as high temperature $\left(40-50^{\circ} \mathrm{C}\right)$ conditions to provide the standards for good quality meat products. Studies showed that TGase supplementation increased gel strength in meat products and had positive effect on the development of product characteristics (Tseng et al., 2000; Serrano et al., 2004; Dondero et al., 2006; Jongjareonrak et al., 2006; Trespalacios \& Pla, 2007; Baytar, 2010; Uran et al., 2013).

The objective of this study was to investigate the organoleptic features and post production quality criteria of chicken burgers produced by supplementation of transglutaminase enzyme, a worldwide used food processing aid since there has been a growing demand for chicken burgers in poultry meat industry of Turkey.

\section{Materials and methods}

\subsection{Preparation of material}

Common procedures was followed for burger production. Fresh, purified from the skin of chicken breast meat was used as a raw material. Chicken meat is well grounded after joining kuter mixing at medium speed for 3-4 round. TGase (microbial source, Activa from Ajinomoto corporation) is participated in specified rate $(0.2 \%, 0.4 \%, 0.6 \%, 0.8 \%$ and $1 \%)$, and then $1-2$ rounds again stirring was continued. Then other additives (ice, emulsion fat, burger mix, antimicrobial subtance, carmine and nitrite) was added separately while the machine will continue to operate. After additives, the machine was operate about 5 minutes.

The mixture was transferred from kuter to the filling machine. The batons are formed by filling the mixture firmly into $12 \mathrm{~cm}$ diameter plastic sheathes. After taken to suspend, the batons was holded in this way for a while. Then the batons were baked and after removal were kept in cold storage until it cools down. Each group batons were taken and were cut into equal sized burger. Burgers was vacuum packed and removed in a heat-insulated container and transported to the laboratory.

\subsection{Proximate composition}

Dry matter, ash, protein analysis by Kjeldahl method of burgers was made according to (Association of Official Analytical Chemists, 1990) and fat analysis by Soxhlet method was made according to (Association of Official Analytical Chemists, 1997).

\subsection{Physicochemical analyses}

The $\mathrm{pH}$ value was determined by dipping the $\mathrm{pH}$ electrode into homogenates of filleted fish in distilled water (1/1) (Uran \& Gokoglu, 2014). All measurements were performed at room temperature using pH-meter (WTW Inolab, Weilhem, Germany). The CIE L (lightness), a (redness) and b (yellowness) values of burgers were determined colorflex HunterLab Color Measurement System (Hunter Associates Laboratory, Inc.). After cut from equal dimensions of each sample, the arithmetic average of five measurements was calculated (American Meat Science Association, 1991). For texture analysis, share Force (Warner-Bratzler) values of samples was determined by texture measuring instrument (Instron Model 3343). Equal dimensions of samples were cut and then heat treated in the oven at $200{ }^{\circ} \mathrm{C}$ for 5 minutes. After heated, texture values were read and recorded by the placed on the device (Niamnuy et al., 2007). For the cooking loss account, burgers were baked on the electric gril for 5 minutes at about $180^{\circ} \mathrm{C}$. Cooking loss of burgers was made on the basis of the weight loss (Bostan et al., 2001).

\subsection{Sensory analyses}

Sensory analyses was performed by a panel of 13 panelists who has burger eating habits. The samples were coded using letters and randomly presented to the panelists. All assessments took place in individual booths in a day light conditions. Panelists were asked to evaluate taste, color, odor and texture samples on a 7-point hedonic scale. An overall quality score was calculated as the mean score of taste, color, odor and texture. The scale was defined as 7 'excellent', 6 'good', 5 'moderate', 4 'fair', 3 'slight poor', 2 'poor', 1 'very poor' (Tseng et al., 2000).

\subsection{Scanning Electron Microscopy (SEM)}

To investigate the microstructure of burger samples, the images were taken by scanning in the Scanning Electron Microscobe (SEM). For this purpose, samples after passing a series of preparation stages, were examined under the microscope. Samples were fixed with a mixture $(1: 1 \mathrm{v} / \mathrm{v})$ of formaldehyde $(4 \%)$ and glutaraldehyde $(0.2 \%)$ in $0.1 \mathrm{M}$ phosphate buffer $(\mathrm{pH} 7.2)$. Next, samples were postfixed with $\mathrm{OsO}_{4}$, ashed and critical-point dried in increasing concentrations of acetone. Samples were then sputter-coated with gold/palladium and examined in LEO 440 Scanning Electron Microscope. The surface of samples scans were performed respectively with different magnifying power and the photos were copied (Moreno et al., 2010).

\subsection{Statistical analysis}

Statistical analysis was conducted using the SAS software (Statistical Analysis System, Cary, NC, USA). When main effects or interactions were significant, Duncan's Multiple Range test was used.

\section{Results and discussion}

The findings related to burger examples (control and enzyme added groups) are given Table 1 and Table 2, respectively.

Dry matter content of burger samples without enzyme supplementation was $44.1 \%$ while this percentage value changed with the addition of the enzyme. The protein levels of the groups containing $0.2 \%$ and $0.4 \%$ of transglutaminase increased in comparison to those of the control while enzyme concentration of $0.6 \%$ and above caused a reduction again in the protein content of the samples. Samples containing $0.4 \%$ of enzyme revealed statistically significant changes $(p<0.05)$ in terms of protein content whereas no statistically significant difference was noted in the control and the other groups containing enzyme at different concentrations (0.2, 0.6, 0.8 and $1 \%)$.

Burger style food products are basically water-in-oil emulsions. Despite the high moisture content in burgers, fat content is also high due to the fat added along with the fat already existing 
Table 1. The analysis findings of burger samples $1^{1}$.

\begin{tabular}{cccccc}
\hline \multicolumn{7}{c}{ Analysis } \\
\hline Product & Dry Matter (\%) & Ash (\%) & Fat (\%) & Protein (\%) & pH value \\
\hline Control & $44.10 \pm 0.05^{\mathrm{b}}$ & $3.30 \pm 0.10^{\mathrm{a}}$ & $23.20 \pm 0.42^{\mathrm{a}}$ & $13.19 \pm 0.36^{\mathrm{a}}$ & $6.39 \pm 0.01^{\mathrm{a}}$ \\
$\mathbf{0 . 2 \%}$ & $44.34 \pm 0.07^{\mathrm{b}}$ & $3.32 \pm 0.59^{\mathrm{a}}$ & $23.19 \pm 0.22^{\mathrm{a}}$ & $13.40 \pm 0.27^{\mathrm{a}}$ & $6.41 \pm 0.01^{\mathrm{a}}$ \\
$\mathbf{0 . 4 \%}$ & $45.37 \pm 0.06^{\mathrm{a}}$ & $3.31 \pm 0.40^{\mathrm{a}}$ & $23.15 \pm 0.11^{\mathrm{a}}$ & $13.56 \pm 0.24^{\mathrm{a}}$ & $6.34 \pm 0.02^{\mathrm{a}}$ \\
$\mathbf{0 . 6 \%}$ & $44.22 \pm 0.13^{\mathrm{b}}$ & $3.29 \pm 0.40^{\mathrm{a}}$ & $23.11 \pm 0.73^{\mathrm{a}}$ & $14.15 \pm 0.17^{\mathrm{a}}$ & $6.38 \pm 0.01^{\mathrm{a}}$ \\
$\mathbf{0 . 8 \%}$ & $43.82 \pm 0.09^{\mathrm{b}}$ & $3.28 \pm 0.07^{\mathrm{a}}$ & $22.07 \pm 0.50^{\mathrm{a}}$ & $14.35 \pm 0.29^{\mathrm{a}}$ & $6.39 \pm 0.01^{\mathrm{a}}$ \\
$\mathbf{1 . 0 \%}$ & $43.63 \pm 0.66^{\mathrm{b}}$ & $3.28 \pm 0.68^{\mathrm{a}}$ & $21.66 \pm 0.45^{\mathrm{a}}$ & $14.41 \pm 0.66^{\mathrm{a}}$ & $6.44 \pm 0.01^{\mathrm{a}}$ \\
\hline
\end{tabular}

${ }^{1}$ Values \pm represent the standard deviation. The averages marked with the same letters in columns are not different statistically ( $\mathrm{p}>0.05$ ).

Table 2. The analysis findings of burger samples $2^{1}$.

\begin{tabular}{|c|c|c|c|c|c|}
\hline \multirow{3}{*}{ Product } & \multicolumn{4}{|c|}{ Analysis } & \\
\hline & \multirow{2}{*}{ Cooking Loss (\%) } & \multirow{2}{*}{ Texture (kgf) } & \multicolumn{3}{|c|}{ Color } \\
\hline & & & $\mathbf{L}$ & $\mathbf{a}$ & $\mathbf{b}$ \\
\hline Control & $21.01 \pm 5.50^{\mathrm{a}}$ & $1.94 \pm 0.22^{c}$ & $50.29 \pm 1.62^{\mathrm{b}}$ & $22.12 \pm 0.91^{\mathrm{ab}}$ & $9.07 \pm 0.68^{\mathrm{ab}}$ \\
\hline $0.2 \%$ & $18.58 \pm 3.75^{\mathrm{ab}}$ & $2.02 \pm 0.21^{\mathrm{c}}$ & $54.93 \pm 3.33^{\mathrm{ab}}$ & $22.62 \pm 1.43^{\mathrm{a}}$ & $9.36 \pm 0.72^{\mathrm{a}}$ \\
\hline $0.4 \%$ & $17.25 \pm 1.93^{\mathrm{ab}}$ & $2.09 \pm 0.28^{c}$ & $56.53 \pm 2.12^{\mathrm{a}}$ & $20.79 \pm 0.76^{\mathrm{b}}$ & $9.91 \pm 0.66^{\mathrm{a}}$ \\
\hline $0.6 \%$ & $16.14 \pm 1.79^{\mathrm{ab}}$ & $2.36 \pm 0.27^{\mathrm{b}}$ & $53.78 \pm 4.11^{\mathrm{ab}}$ & $23.51 \pm 1.38^{\mathrm{a}}$ & $8.32 \pm 0.78^{b}$ \\
\hline $0.8 \%$ & $12.89 \pm 2.28^{\mathrm{ab}}$ & $2.44 \pm 0.11^{\mathrm{b}}$ & $54.04 \pm 5.72^{\mathrm{ab}}$ & $23.36 \pm 1.63^{\mathrm{a}}$ & $8.96 \pm 0.69^{\mathrm{ab}}$ \\
\hline $1.0 \%$ & $10.47 \pm 1.08^{\mathrm{b}}$ & $2.89 \pm 0.47^{\mathrm{a}}$ & $54.64 \pm 3.07^{\mathrm{ab}}$ & $22.54 \pm 0.84^{\mathrm{a}}$ & $9.77 \pm 0.64^{\mathrm{a}}$ \\
\hline
\end{tabular}

${ }^{1}$ Values \pm represent the standard deviation. The averages marked with the same letters in columns are not different statistically ( $\mathrm{p}>0.05$ ).

within the meat. Food additives used for different purposes and the high fat content result in an increase in dry matter and thus the moisture content is decreased. However, crosslinking of protein molecules is the most significant effect of TGase and there is a direct correlation between enzyme concentration and the amount of cross links generated. Formation of these bonds and the elevation in their number increase water holding capacity within the product and thus moisture content of the samples is increased as well. Accordingly, increased molecular bonds were considered to be the main cause of the rise in moisture content of our samples in parallel with the elevation in enzyme concentration.

Cofrades et al. (2011) investigated the quality parameters of chicken steaks supplemented with TGase and detected no statistical significance among the samples in terms of dry matter content.

Uran et al. (2013) produced chicken patties made from chicken breast by processing them with various spices. They investigated the quality properties of these patties treated with two different concentrations ( 0.5 and 1\%) of TGase. Enzyme supplementation caused an increase in dry matter content and a statistical significance $(\mathrm{p}<0.05)$ was noted in the group that was administered $1 \%$ of enzyme in comparison with that of the control.

Ash content of burgers without TGase supplementation was found to be $3.3 \%$ in our study and no statistically significant difference ( $p>0.05)$ was detected between the control and the enzyme-supplemented groups in terms of ash content of the samples. Similarly, no statistical significance was shown with respect to ash content of TGase-added chicken patties and chicken steaks in different studies (Uran et al., 2013; Cofrades et al., 2011).

In our study, fat content of burgers did not show statistically significant $(p>0.05)$ difference between enzyme-supplemented and non-enzyme groups. Besides, fat content of non-enzyme group was $23.20 \%$, while fat content of enzyme-supplemented groups decreased inversely with the increasing enzyme concentration and fat content of the samples supplemented with $1 \%$ of enzyme concentration was detected to be $21.66 \%$. Likewise, no statistically significant difference was detected in terms of fat content of TGase-supplemented chicken steaks and patties prepared from chicken breast in some studies (Cofrades et al., 2011; Uran et al., 2013).

In this study, protein content of non-enzyme supplemented group was found to be $13.19 \%$ whereas protein contents of enzyme-treated groups at different concentrations $(0.2,0.4,0.6,0.8$ and $1 \%)$ were detected to be $13.40,13.56,14.15,14.35$ and $14.41 \%$, respectively and the difference was not statistically significant $(\mathrm{p}>0.05)$. The increase in protein content in parallel to the increase in enzyme concentrations was an expected outcome since enzymes are protein based molecules which contribute to the increase in protein content of the samples. Similar results were obtained in some studies however the increase was not statistically significant among different groups (Uran et al., 2013; Cofrades et al., 2011).

$\mathrm{pH}$ value of non- enzyme group was 6.39 while this value was found to be 6.44 in the enzyme treated group at highest concentration (1\%) Therefore enzyme supplementation did not affect $\mathrm{pH}$ level of burger samples and no statistically significant changes occurred ( $p>0.05)$. Uran et al. (2013) reported that enzyme supplementation caused a slight increase $(p<0.05)$ in the acidity of chicken patties and no difference was noted between two concentrations ( 0.5 and $1 \%$ ) of enzyme in terms of $\mathrm{pH}$ levels. Trespalacios \& Pla (2007) used TGase (1\%) concurrently with pressure to develop functional properties of chicken breast gel and $\mathrm{pH}$ level was detected to be 6.89 in non-enzyme supplemented group. And they observed a slight increase (6.84) in the acidity of enzyme-added samples. 
TGase increases the water holding capacity of meat products by decreasing cooking and thawing losses (Pietrasik et al., 2007). Our findings also strongly supported this hypothesis. Cooking loss in non-enzyme treated samples was estimated to be $21.01 \%$. Cooking losses decreased inversely with the increased enzyme concentration and this decrease $(10.47 \%)$ was statistically significant $(\mathrm{p}<0.05)$ in $1 \%$ enzyme-supplemented samples in comparison to the control group. No statistically significant difference $(\mathrm{p}>0.05)$ was noted between two enzyme groups in terms of cooking loss.

Data obtained from the studies with respect to TGase enzyme clearly pointed out that the decrease in cooking loss was one of the most prominent differences between enzyme supplemented and non-enzyme supplemented products. Pietrasik (2003) reported that enzyme supplementation of $0.5 \%$ markedly decreased moisture and weight losses of cattle gels that were subjected to commercial cooking methods. In a study with respect to TGase supplemented chicken patties $1 \%$ enzyme supplementation significantly decreased cooking loss in comparison to the control group (Uran et al., 2013). Our findings were compatible with those of the relevant studies and data obtained.

On the basis of our findings, the texture value of burger samples increased parallel to the increase in enzyme concentration when compared with that of the control group. Texture values of enzyme supplementation at $0.2,0.4,0.6,0.8$ and $1 \%$ concentrations were determined to be 2.02, 2.09, 2.36, 2.44 and 2.89, respectively while those of non-enzyme supplemented group were measured to be $1.94 \mathrm{kgf}$. When statistically evaluated, no difference ( $\mathrm{p}>0.05$ ) was noted between the control group and $0.2 \%$ and $0.4 \%$ enzyme-supplemented groups. Likewise, $0.6 \%$ and $0.8 \%$ enzyme-supplemented groups did not show a significant difference $(\mathrm{p}>0.05)$ between each other although texture values of these two differed significantly from all other groups $(\mathrm{p}<0.01)$. The highest texture value belonged to $1 \%$ enzyme-supplemented group, which was statistically significant in comparison to those of other groups $(\mathrm{p}<0.01)$.

In a study regarding the utilization of MTGase supplementation in chicken patties, it was shown that the presence of the enzyme and its elevated concentrations significantly increased the texture value of the products (Uran et al., 2013). Ahhmed et al. (2007) investigated the changes in gel strength of MTGase-supplemented chicken and cattle sausages and found out that amount of G/L bands remarkably increased after the enzyme application and thus contributed to the improvement of meat texture in various ways. Tseng et al. (2000) indicated that TGase supplementation at different concentrations $(0,0.05,0.1,0.2,0.4$ and $1 \%)$ increased the gel strength of chicken patties concurrently with the elevation of the enzyme concentration added to the products and in particular enzyme concentration of $0.2 \%$ and above had a significant influence $(\mathrm{p}<0.01)$ on the rise in gel strength when compared with that of the control group. Lantto et al. (2007) investigated the effects of laccase and TGase on the compactness and weight loss of cooked chicken homogenate gels and detected that compactness of low-salt (1\%) low-meat (65\%), phosphate free gels was decreased and with some amount of TGase supplementation, the consistency of the same samples significantly improved in comparison to that of the non-enzyme supplemented control group. In addition, they consequently found out that TGase conclusively improved the gel strength in both low-meat and high-meat (75\%) homogenates.

In the study, enzyme application did not exhibit significant effects on coloring values of burger samples, instead generated rather alternating changes. "L" values (lightness) increased in enzyme-supplemented groups when compared with those of the control group while no statistically significant change was observed among the enzyme-supplemented groups ( $\mathrm{p}>0.05)$. "L" value of the control group was found to be 50.29 whereas the highest " $L$ " value was 56.53 in $0.4 \%$ enzyme-supplemented group, which was statistically significant in comparison to that of the control group $(\mathrm{p}<0.01)$.

The highest "a" value (redness) was 23.51 in $0.6 \%$ enzyme-supplemented group while the lowest "a" value (20.79) was observed in $0.4 \%$ enzyme-supplemented group, which was a statistically significant decrease when compared with the other enzyme-supplemented samples $(\mathrm{p}<0.01)$. On the contrary, no significant difference was noted between the control group and $0.4 \%$ enzyme-supplemented group ( $p>0.05$ ). Likewise, no statistically significant difference $(\mathrm{p}>0.05)$ was detected among other enzyme-supplemented groups $(0.2,0.6,0.8$ and $1 \%)$.

When " $b$ " value was evaluated (yellowness), the findings were compatible with those of "a" value. "b" value of the control group was 9.07 whereas the highest " $b$ " value was 9.91, which belonged to $0.4 \%$ enzyme-supplemented group and $0.6 \%$ enzyme-supplemented group revealed the lowest " $b$ " value of 8.32. Statistically, similar values were observed between the control group and $0.2,0.4,0.8$ and $1 \%$ enzyme-supplemented groups as well as those between the control group and 0.6 and $0.8 \%$ enzyme-supplemented groups ( $\mathrm{p}>0.05)$. When the enzyme-supplemented groups were evaluated no statistically significant change was noted either among $0.2,0.4,0.8$ and $1 \%$ enzyme-supplemented groups or between $0.6 \%$ and $0.8 \%$ enzyme-supplemented groups ( $\mathrm{p}>0.05)$.

Tseng et al. (2000) reported that "L"(lightness), "a" (redness) and "b" (yellowness) values of low salt chicken patties supplemented with TGase at different concentrations ranged between 71.16-74.66; 1.86-2.42 and 11.0-13.46, respectively. And these chances were of no significance. Nielsen et al. (1995) indicated that TGase supplementation decreased "a" values in comparison to those of the control group which was associated with the variety in myoglobin content of different meat types used. For instance myoglobin content of pork meat was much higher than that of chicken breast meat. Trespalacios \& Pla (2007) did not find out a difference between TGase-supplemented and non-enzyme supplemented groups in terms of " $b$ " value of chicken meat gels processed at the same temperature and under the same atmospheric pressure. Furthermore, pressure decreased yellow coloring in non-enzyme supplemented samples whereas temperature $\left(20\right.$ and $\left.40^{\circ} \mathrm{C}\right)$ decreased yellow coloring in all samples including enzyme-supplemented and non-enzyme supplemented groups. Pietrasik (2003) showed that MTGase application increased " $b$ " values in cattle gels processed with egg white at $80^{\circ} \mathrm{C}$ for $14 \mathrm{~min}$. Likewise, Hammer (1998) pointed out a linear correlation which was manifested as a decrease between enzyme concentration $(0-0.2 \%)$ and " $b$ " values in finely sliced 
and cooked sausages. Both researches reported no difference in "L" and "a" values.

In addition, previous studies demonstrated the ineffectiveness of TGase on coloring parameters of chicken meat products like doner kebap (K1lıc, 2003) and low-salt chicken patties (Tseng et al., 2000; Uran et al., 2013) as well.

The sensory analyses findings are given in Table 3 . According to the findings obtained in our research, there was not found a statistically significant difference $(p>0.05)$ between all samples that contains enzyme and enzyme-free examined by the panel in terms of 4 sensory criteria (color, taste, smell and texture). When the samples of each group examined in their own for the overall acceptability in terms of these 4 criteria, the highest value was observed in $1 \%$ enzyme added group as 5.53 and the lowest value as 4.65 in the $0.6 \%$ enzyme added group. The datas obtained in the panel proved that, the increase in the amount of enzyme did not cause any negativity in terms of color, taste, odor and texture compared to the enzyme-free samples.

Many researches done on the subject seem similar with our work. When Tseng et al. (2000) assessed the chicken burgers produced by the addition of various concentrations of TGase in terms of sensory, they determined no significant changes between the samples in terms of appearance, color and aroma. However, addition of $1 \%$ enzyme caused a significant effect on the texture, juiciness and overall acceptability.

Chanyongvorakul et al. (1995) reported an elastic and viscoelastic structure in TGase added chicken gels due to contribute to the elasticity and texture of the product.

Cofrades et al. (2011)'s sensory analysis results of chicken steaks produced from chicken breast meat with using TGase and seaweed showed that addition of seaweed and MTGase/caseinate was effective in significantly on the sensory properties of chicken steaks. The panel was aware of the addition of seaweed but they did not taste the addition of MTGase/caseinate as non-meat flavor. Panel did not scored the taste, flavor and overall acceptability of the products as negative and gave close points above 5 out of 10 . Also panel did not found any differences between the texture of the products compared to the control group ( $p>0.05)$.

SEM photomicrographs are shown in Figure 1. When we look at the photomicrographs, the G-L ( $\varepsilon$ ( $\gamma$-glutamil)-lisil)

Table 3. The sensory analyses findings of burger samples ${ }^{1}$.

\begin{tabular}{lcccccc}
\hline \multicolumn{1}{c}{ Analysis } & Control & $\mathbf{0 . 2 \%}$ & $\mathbf{0 . 4 \%}$ & $\mathbf{0 . 6 \%}$ & $\mathbf{0 . 8 \%}$ & $\mathbf{1 \%}$ \\
\hline Colour & $5.37 \pm 1.30$ & $4.75 \pm 0.88$ & $5.75 \pm 0.70$ & $5.12 \pm 1.45$ & $5.25 \pm 0.88$ & $5.50 \pm 0.53$ \\
Taste & $4.87 \pm 1.55$ & $4.37 \pm 0.51$ & $5.25 \pm 1.48$ & $4.50 \pm 1.77$ & $5.37 \pm 1.06$ & $5.50 \pm 0.75$ \\
Odor & $4.87 \pm 1.24$ & $4.50 \pm 0.92$ & $4.75 \pm 0.88$ & $4.50 \pm 1.60$ & $5.37 \pm 1.30$ & $5.37 \pm 0.74$ \\
Texture & $6.00 \pm 1.06$ & $5.25 \pm 0.88$ & $5.87 \pm 1.12$ & $4.50 \pm 1.51$ & $6.12 \pm 0.83$ & $5.75 \pm 0.70$ \\
General Evaluation & $5.27 \pm 0.25$ & $4.71 \pm 0.16$ & $5.40 \pm 0.42$ & $4.65 \pm 0.31$ & $5.52 \pm 0.06$ & $5.53 \pm 0.05$ \\
\hline
\end{tabular}

${ }^{1}$ Values \pm represent the standard deviation. There is no statistical differences between avarages $(\mathrm{p}>0.05)$
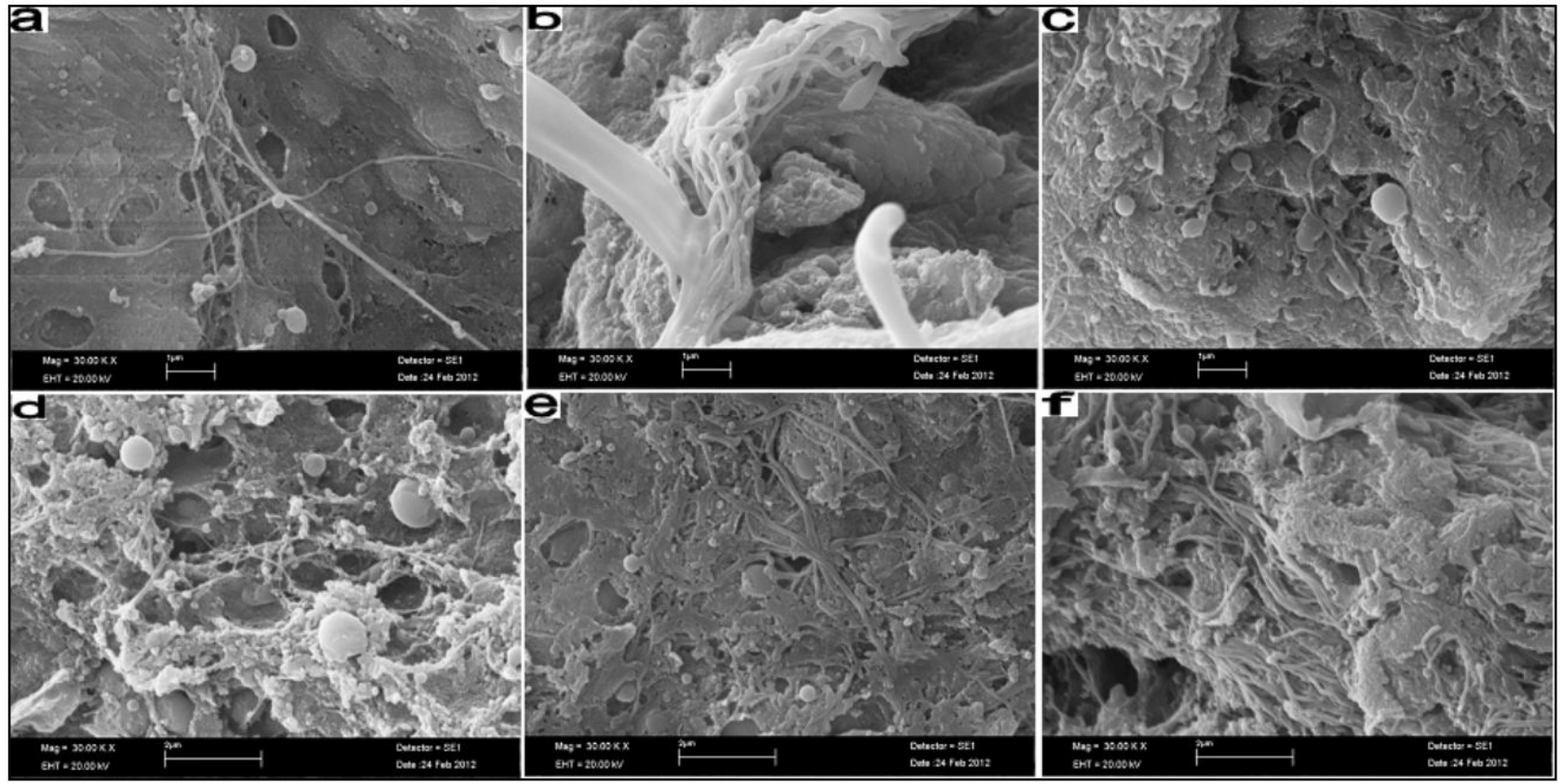

Figure 1. SEM (Scanning Electron Microscope) images of burger samples. (a) Magnified 30000 times SEM image of the control group; (b) Magnified 30000 times SEM image of the $0.2 \%$ enzyme added group; (c) Magnified 30000 times SEM image of the $0.4 \%$ enzyme added group; (d) Magnified 30000 times SEM image of the $0.6 \%$ enzyme added group; (e) Magnified 30000 times SEM image of the $0.8 \%$ enzyme added group; (f) Magnified 30000 times SEM image of the $1 \%$ enzyme added group. 
connections were rarely seen in the enzyme-free control group samples; it was seen that the gel network loose and irregular, large holes in this structure. It is observed that the gel network structure is more compact and dense in the TGase added samples. Furthermore, it is observed that the holes become smaller in their surface with the increase of the amount of enzyme in the samples.

The main result of the studies performed with TGase enzyme is; increasing of textures and gel network structures of the products and the cause of this result is due to the increase of the formation of intermolecular $\varepsilon$ ( $\gamma$-glutamyl)-lisil cross-links with the enzyme addition. In our research, it is aimed to observation of the gel network structure in the products.

Tseng et al. (2000), also made microstructure analysis in their study to determine the quality of the TGase enzyme added chicken meatballs and when the examine SEM (Scanning Electron Microscope) of photo-microstructure as a result of this analysis; they observed looser gel network structures in the TGase-free control group samples. In addition to this they determined more stringent and regular network structure in TGase added meatballs. Also, structure was observed to be larger and gel clusters were found to be more completed in \%1 TGase enzyme added samples.

In another research, changes in physicochemical properties of raw-appearing restructured models made from hake (Merluccius capensis) muscle, using cold gelation technology by addition of sodium alginate and microbial transglutaminase (MTGase), were studied during frozen storage at $-15^{\circ} \mathrm{C}$. Among the more interesting results, addition of MTGase produced more protein aggregation in models processed by muscle homogenization and thus the protein network that formed in the gel was better than in samples with added sodium alginate (Moreno et al., 2010). MTGase $(0.3 \%)$ was added to chicken batters in order to investigate the combined effect of pressure and enzyme on the functional properties of gels in another study. According to the results, the network of gel without MTGase was loose with big, irregular holes; however, a more compact and homogeneous structure was observed when MTGase was present (Trespalacios \& Pla, 2007). Ahhmed et al. (2009) was investigated the difference between chicken and beef in the interaction of actomyosin (myosin B) with MTGase. They reported that the gel strength of myosin B was improved in both species and was significantly greater in beef than in chicken. It was concluded that molecules of myosin B treated with MTGase in the samples can be turned into quite large size and complex structures.

\section{Conclusion}

Transglutaminases are mass enzymes manufactured at low costs. The manufacturing procedure is fast and easy. These enzymes exhibit many properties like functioning as a catalyzer for cross-linking of various molecules. They are more reliable products with more practical application when compared with their chemical counterparts used for the same purposes and thus are high potential food processing aids.

The study in which we investigated the quality parameters of burgers prepared from chicken breasts and processed with
TGase supplementation consequently revealed varying changes in nutritional properties of the product. The increase in the amount of enzyme similarly increased dry mass content and protein level of the samples. Enzyme supplementation did not alter the coloring and $\mathrm{pH}$ level and the organoleptic standards of the product. The most dramatic change was manifested by the increase in textural and structural properties and the significant decrease in cooking loss of the product as frequently mentioned. Scanning electron microscope (SEM) images of the samples confirmed the elevation of intermolecular bonds between proteins.

Owing to transglutaminase, high quality meat (red meat/fish) components are to be cross linked, which consequently reduce residual and loss content and thus lower the price of the final product. Therefore enzyme supplementation is undoubtedly considered to be a valuable contribution for sustainable food chain which in return is expected to aid in reducing the effects of unfavorable environmental factors on agriculture by maximizing prepared foodstuff production.

\section{Acknowledgements}

This Scientific Research supported from Projects Administration Unit of Namık Kemal University under project no. 00.24.DR.09.03.

\section{References}

Ahhmed, A. M., Kawahara, S., Ohta, K., Nakade, K., Soeda, T., \& Muguruma, M. (2007). Differentiation in improvements of gel strength in chicken and beef sausages induced by transglutaminase. Meat Science, 76(3), 455-462. PMid:22060987. http://dx.doi.org/10.1016/j. meatsci.2007.01.002.

Ahhmed, A. M., Nasu, T., Huy, D. Q., Tomisaka, Y., Kawahara, S., \& Muguruma, M. (2009). Effect of microbial transglutaminase on the natural actomyosin cross-linking in chicken and beef. Meat Science, 82(2), 170-178. PMid:20416767. http://dx.doi.org/10.1016/j. meatsci.2009.01.007.

American Meat Science Association - AMSA. (1991). Guidelines for meat color evaluation. Chicago: National Live Stock and Meat Board.

Association of Official Analytical Chemists - AOAC. (1990). Official methods of analyses of Association of Analytical Chemist (15th ed.). Washington: AOAC.

Association of Official Analytical Chemists - AOAC. (1997). Official methods of analyses of Association of Analytical Chemist (16th ed.). Washington: AOAC.

Baytar, B. (2010). Modeling of the effects of transglutaminase enzyme and $\mathrm{NaCl}$ on the various properties of chicken patties by response surface method. Van: Yuzuncu Yil University.

Bostan, K., Ugur, M., \& Çetin, O. (2001). Studies on poultry meat salami production. Journal of the Faculty of Veterinary Medicine, 27(2), 631-644.

Bourneow, C., Benjakul, S., Sumpavapol, P., \& Kittikun, A. H. (2012). Isolation and cultivation of transglutaminase producing bacteria from seafood processing factories. Innovative Romanian Food Biotechnology, 10(3), 28-39.

Chanyongvorakul, Y., Matsumura, Y., Nonaka, M., Motoki, M., \& Mori, T. (1995). Physical properties of soy bean and broad bean 11 S globulin gels formed by transglutaminase reaction. Journal of Food Science, 60(3), 483-488. http://dx.doi.org/10.1111/j.1365-2621.1995.tb09808.x. 
Cofrades, S., Lopez, I. L., Capillas, C. R., Triki, M., \& Colmenero, F. J. (2011). Quality characteristics of low-salt restructured poultry with microbial transglutaminase and seaweed. Meat Science, 87(4), 373380. PMid:21145666. http://dx.doi.org/10.1016/j.meatsci.2010.11.014.

Dondero, M., Figueroa, V., Morales, X., \& Curotto, E. (2006). Transglutaminase effects on gelation capacity of thermally induced beef protein gels. Food Chemistry, 99(3), 546-554. http://dx.doi. org/10.1016/j.foodchem.2005.08.022.

Farnsworth, J. P., Li, J., Hendricks, G. M., \& Guo, M. R. (2006). Effects of transglutaminase treatment on functional properties and probiotic culture survivability of goat milk yogurt. Small Ruminant Research, 65(1-2), 113-121. http://dx.doi.org/10.1016/j.smallrumres.2005.05.036.

Hammer, G. F. (1998). Microbial transglutaminase and diphosphate in finely comminuted cooked sausage. Fleischwirtschaft, 78(11), 1155-1186.

Jongjareonrak, A., Benjakul, S., Visessanguan, W., \& Tanaka, M. (2006). Skin gelatin from bigeye snapper and brownstripe red snapper: chemical composition and effect of microbial transglutaminase on gel properties. Food Hydrocolloids, 20(8), 1216-1222. http://dx.doi. org/10.1016/j.foodhyd.2006.01.006.

Kılıc, B. (2003). Effect of microbial transglutaminase and sodium caseinate on quality of chicken doner kebab. Meat Science, 63(3), 417-421. PMid:22062396. http://dx.doi.org/10.1016/S0309-1740(02)00102-X.

Lantto, R., Plathin, P., Niemistö, M., Buchert, J., \& Autio, K. (2006). Effects of transglutaminase, tyrosinase and freeze-dried apple pomace powder on gel forming and structure of pork meat. $L W T$ Food Science and Technology, 39(10), 1117-1124. http://dx.doi. org/10.1016/j.lwt.2005.07.008.

Lantto, R., Puolanne, E., Katina, K., Niemistö, M., Buchert, J., \& Autio, K. (2007). Effect of laccase and transglutaminase on the textural and water-binding properties of cooked chicken breast meat gels. European Food Research and Technology, 225(1), 75-83. http://dx.doi. org/10.1007/s00217-006-0384-z.

Moreno, H. M., Carballo, J., \& Borderias, A. J. (2010). Use of microbial transglutaminase and sodium alginate in the preparation of restructured fish models using cold gelation: effect of frozen storage. Innovative Food Science \& Emerging Technologies, 11(2), 394-400. http://dx.doi. org/10.1016/j.ifset.2009.12.002.

Motoki, M., \& Seguro, K. (1998). Transglutaminase and its use for food processing. Trends in Food Science \& Technology, 9(5), 204-210. http://dx.doi.org/10.1016/S0924-2244(98)00038-7.

Niamnuy, C., Devahastin, S., \& Soponronnarit, S. (2007). Quality changes of shrimp during boiling in salt solution. Journal of Food Science, 72(5), 289-297. PMid:17995744. http://dx.doi.org/10.1111/j.17503841.2007.00349.x.

Nielsen, G. S., Petersen, B. R., \& Moller, A. J. (1995). Impact of salt, phosphate and temperature on the effect of a transglutaminase on the texture of restructured meat. Meat Science, 41(3), 293-299. PMid:22060200. http://dx.doi.org/10.1016/0309-1740(94)00002-O.

Nio, N., Motoki, M., \& Takinami, K. (1986). Gelation mechanism of protein solution by transglutaminase. Agricultural and Biological
Chemistry Journal, 50(4), 851-855. http://dx.doi.org/10.1080/000 21369.1986.10867499.

Pietrasik, Z. (2003). Binding and textural properties of beef gels processed with $\kappa$-carrageenan, egg albumin and microbial transglutaminase. Meat Science, 63(3), 317-324. PMid:22062383. http://dx.doi. org/10.1016/S0309-1740(02)00088-8.

Pietrasik, Z., Jarmoluk, A., \& Shand, P. J. (2007). Effect of non-meat proteins on hydration and textural properties of pork meat gels enhanced with microbial transglutaminase. LWT-Food Science and Technology, 40(5), 915-920. http://dx.doi.org/10.1016/j.lwt.2006.03.003.

Saguer, E., Fort, N., Pares, D., Toldra, M., \& Carretero, C. (2007). Improvement of gelling properties of porcine blood plasma using microbial transglutaminase. Food Chemistry, 101(1), 49-56. http:// dx.doi.org/10.1016/j.foodchem.2005.11.050.

Serrano, A., Cofrades, S., \& Calmenero, J. F. (2004). Transglutaminase as binding agent in fresh restructed beef steak with added walnuts. Food Chemistry, 85(3), 423-429. http://dx.doi.org/10.1016/j. foodchem.2003.07.021.

Soares, L. H. B., Albuquerque, P. M., Assmann, F., \& Ayub, M. A. Z. (2004). Physicochemical properties of three food proteins treated with transglutaminase. Ciencia Rural, 34(4), 1219-1223. http:// dx.doi.org/10.1590/S0103-84782004000400039.

Sun, X. D., \& Arntfield, S. D. (2011). Gelation properties of chicken myofibrillar protein induced by transglutaminase crosslinking. Journal of Food Engineering, 107(2), 226-233. http://dx.doi.org/10.1016/j. jfoodeng.2011.06.019.

Trespalacios, P., \& Pla, R. (2007). Simultaneous application of transglutaminase and high pressure to improve functional properties of chicken meat gels. Food Chemistry, 100(1), 264-272. http://dx.doi. org/10.1016/j.foodchem.2005.09.058.

Tseng, T. F., \& Cheng, M. T. C. (2002). Purification of transglutaminase and its effects on myosin heavy chain and actin of spent hens. Meat Science, 60(3), 267-270. PMid:22063397. http://dx.doi.org/10.1016/ S0309-1740(01)00132-2.

Tseng, T. F., Liu, D. C., \& Chen, M. T. (2000). Evaluation of transglutaminase on the quality of low-salt chicken meat-balls. Meat Science, 55(4), 427-431. PMid:22061575. http://dx.doi.org/10.1016/ S0309-1740(99)00172-2.

Uran, H., \& Gokoglu, N. (2014). Effects of cooking methods and temperatures on nutritional and quality characteristics of anchovy (Engraulis encrasicholus). Journal of Food Science and Technology, 51(4), 722-728. PMid:24741166. http://dx.doi.org/10.1007/s13197011-0551-5.

Uran, H., Aksu, F., Yilmaz, I., \& Durak, M. Z. (2013). Effect of transglutaminase on the quality properties of chicken breast patties. Journal of the Faculty of Veterinary Medicine, 19(2), 331-335. http:// dx.doi.org/10.9775/kvfd.2012.7842.

Yokoyama, K., Nio, N., \& Kikuchi, Y. (2004). Properties and applications of microbial transglutaminase. Applied Microbiology and Biotechnology, 64(4), 447-454. PMid:14740191. http://dx.doi.org/10.1007/s00253003-1539-5. 